\title{
Effect of Frusemide, Lactose, and Urea on Urinary Cell Loss
}

\author{
A. E. GENT,* M.B., M.R.C.P. ; J. F. N. TAYLOR, † M.B., D.C.H., M.R.C.P. ; C. G. D. BROOK, $\ddagger$ M.B., M.R.C.P.
}

Brit. med. F., 1968, 4, 294-296

Cummary : With the use of a staining method by which cells in the urine can be differentiated, the effect of oral frusemide, lactose, and urea on the rate of excretion of these cells was investigated in five healthy persons.

It is shown that frusemide greatly increases the urinary excretion of red cells, white cells, and renal tubular cells. Similar though not so marked changes were produced by both lactose and urea. Possible reasons for the increased excretion of cells are discussed. One is that it may be the result of an increase in the rate of urinary flow.

\section{Introduction}

Since salicylates were first used therapeutically there have been reports of the effects of aspirin on the kidney of animals and man (Vinci, 1905 ; Chistoni and Lapresa, 1909 ; Scott and Hanzlik, 1916). Papers reporting similar changes with other drugs have been much less frequent (Little and de Wardener, 1962 ; Katz et al., 1962 ; Briggs et al., 1963 ; Mioli et al., 1965). The shortcoming of the quoted work is that no attempt was made to distinguish between white cells and tubule cells in the urine, the two groups being counted together as non-squamous epithelial cells.

The introduction by Prescott and Brodie (1964) of a staining technique by which red cells, white cells, and tubule cells in the urine could be distinguished and thus their individual excretion rates measured overcame this difficulty. This method was used by Prescott (1965) in a study of the effect of analgesic drugs on urinary cell loss.

Other drugs have not been subjected to such an investigation, and it seemed to us that the effect of other drugs which are in common use should be tested in the same way. Frusemide, a diuretic which is widely used clinically, was chosen for this study because of its obvious effect on the kidney. The decision to study the effect of lactose was made because it is a substance which is normally handled by the kidney. Urea was included in the trial because not only is it normally handled by the kidney, but in large amounts it has a diuretic action of its own.

\section{Materials and Methods}

Five healthy male volunteers aged 27 to 36 years were given five-day courses of lactose and frusemide ; in addition, two of the volunteers took urea by mouth for five days. The administration of urea caused vomiting and unpleasant abdominal discomfort, and each subject had to make two attempts before a five-day trial period was completed. Because of these sideeffects urea was not given to the other three subjects. The administration of these drugs followed a five-day control period when, as for the rest of the trial, the subjects were in no way restricted in their diet or fluid intake. The blood pressure was normal in all the subjects and there was no previous history

* Research Assistant, St. Thomas's Hospital, London S.E.1.

t Medical Registrar, St. Thomas's Hospital, London S.E.1. Present address: Medical Registrar, Cardiothoracic Unit, Hospital for Sick Children, Great Ormond Street, London W.C.1.

‡ Medical Registrar, St. Thomas's Hospital, London S.E.1. Present address: House-physician, Hospital for Sick Children, Great Ormond Street, London W.C.1. of renal disease. None were receiving treatment with drugs, and none had taken analgesics in the preceding six weeks.

The routine followed for collection of the urine samples was the same in all cases. At midnight on the first day the bladder was emptied and the first specimen was for the eight hours until 8 a.m., the second specimen was from 8 a.m. until noon, and the third specimen was from noon until 4 p.m. Between 4 p.m. and midnight the urine passed was discarded. This procedure was followed for five days and formed the control period.

During the second week the first two subjects received $15 \mathrm{~g}$. of urea as a solution three times a day, taken at the start of each collection period. During the third week $25 \mathrm{~g}$. of lactose was taken three times each day, and in the fourth week $20 \mathrm{mg}$. of frusemide three times a day. The third, fourth, and fifth subjects did not take urea for a week, but in all other respects the regimen was the same.

Each urine sample was stained by the method of Prescott and Brodie (1964) and the renal tubular cells, white cells, and red cells, thus differently stained, were counted. By this method both the renal tubular cells and epithelial cells from the lower urinary tract are stained pink, but they can be differentiated without difficulty by their morphology (Rofe, 1955). In the main, cell counts were performed by a technician who was unaware of the identity of the drugs, but some counts were carried out by two of us (A.E.G. and J.F.N.T.). For three of the subjects all counts were done by the technician. The drug trial samples, apart from the urea period, and samples from $80 \%$ of the control periods in the other two subjects also were counted by the technician. The excretion rate of each cell type was calculated by the method of Prescott and Brodie (1964) for each specimen of urine. The volume of urine passed in each period was measured and the urine flow rates were calculated.

\section{Results}

The main total cell counts, standard deviations, and $\mathrm{P}$ values for the control and drug trial periods are set out in the Table. The calculations for cells per hour were based on the three urine samples in each 24 hours, and not on the highest value alone.

Mean Urinary Cell Excretion Rates for Five Subjects. $P$ Values Are Calculated by Comparison with Control Rates

\begin{tabular}{|c|c|c|c|c|}
\hline \multirow{2}{*}{$\begin{array}{l}\text { Urinary } \\
\text { Cell Type }\end{array}$} & \multirow[b]{2}{*}{$\begin{array}{l}\text { Control } \\
\text { Cells/hr. (S.D.) }\end{array}$} & \multicolumn{3}{|c|}{ Drug Administered } \\
\hline & & $\begin{array}{c}\text { Urea }^{*} \\
\text { Cells/hr. (S.D.) }\end{array}$ & \begin{tabular}{c|} 
Lactose \\
Cells/hr. (S.D.)
\end{tabular} & $\begin{array}{c}\text { Frusemide } \\
\text { Cells/hr. (S.D.) }\end{array}$ \\
\hline Red .. & $2,980(642)$ & $4,031(803)$ & $3,496(627)$ & $6,069(2,213)$ \\
\hline White & $5,064(1,611)$ & $6,125(1,712)$ & 4,738 (2,755) & $\begin{array}{l}11,063(7,086) \\
P<0.002\end{array}$ \\
\hline Tubule & $2,821(670)$ & $\begin{array}{l}4,297(1,013) \\
P<0.001\end{array}$ & $\begin{array}{l}4,709(1,806) \\
P<0.001\end{array}$ & $\begin{array}{c}13,165(6,307) \\
P<0.0001\end{array}$ \\
\hline
\end{tabular}

* Results for two subjects. N.S. $=$ Not significant. S.D. $=$ Standard deviation.

Frusemide.-The most pronounced changes in cell excretion were produced by frusemide. All three cell types showed a highly significant increase, but it was the excretion of renal tubular cells which showed the greatest difference $(P<0.0001)$ The possibility was considered that the statistically highly significant increase in cell loss might have been due to the 
very high excretion rates produced on some days. Therefore the significance was recalculated for renal tubular cell loss after the six highest values had been removed. The increase in renal tubular cell loss caused by frusemide was found still to be significant $(\mathrm{P}<0.001)$. These changes are set out diagrammatically in Figs. 1, 2, and 3 ; the individual subjects each showed a large increase.

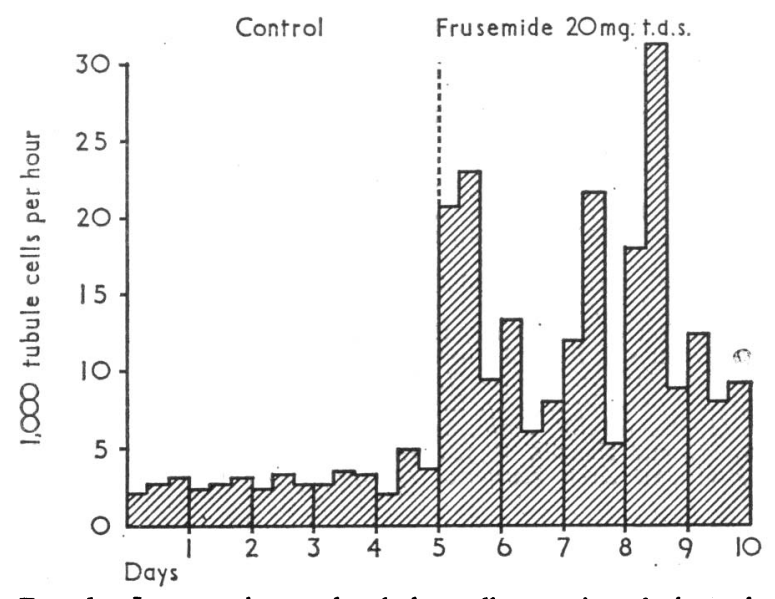

FIG. 1.-Increase in renal tubular cell excretion during administration of frusemide $20 \mathrm{mg}$. t.d.s.

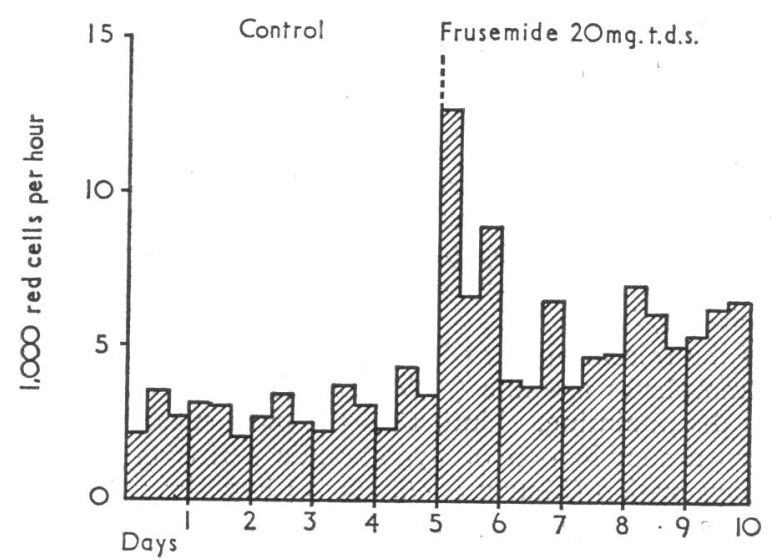

FIG. 2.-Increase in red cell excretion during administration of frusemide $20 \mathrm{mg}$. t.d.s.

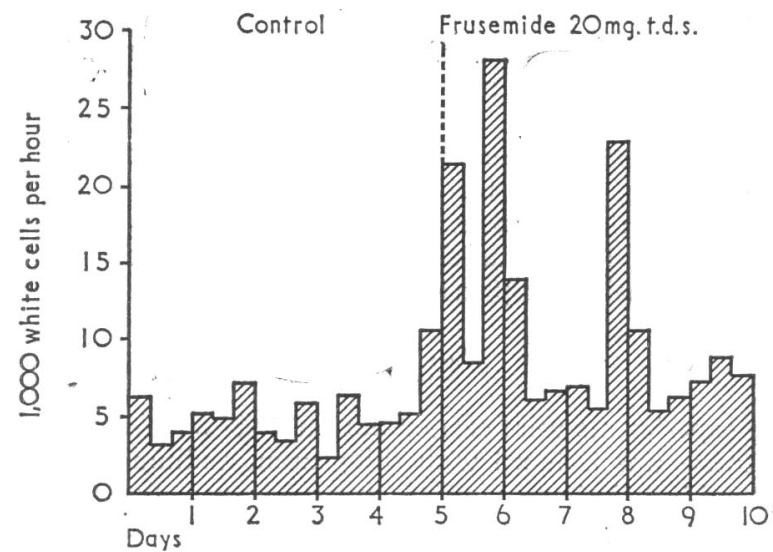

FIG. 3.-Increase in white cell excretion during administration of frusemide $20 \mathrm{mg}$. t.d.s.

Lactose and Urea.-There was no change in red and white cell excretion after the administration of lactose, but there was a significant increase in renal tubular cell loss $(P<0.001)$, which is represented in Fig. 4. Urea caused a significant increase in erythrocyte and renal tubular cell excretion, but there was no significant change in the output of leucocytes.

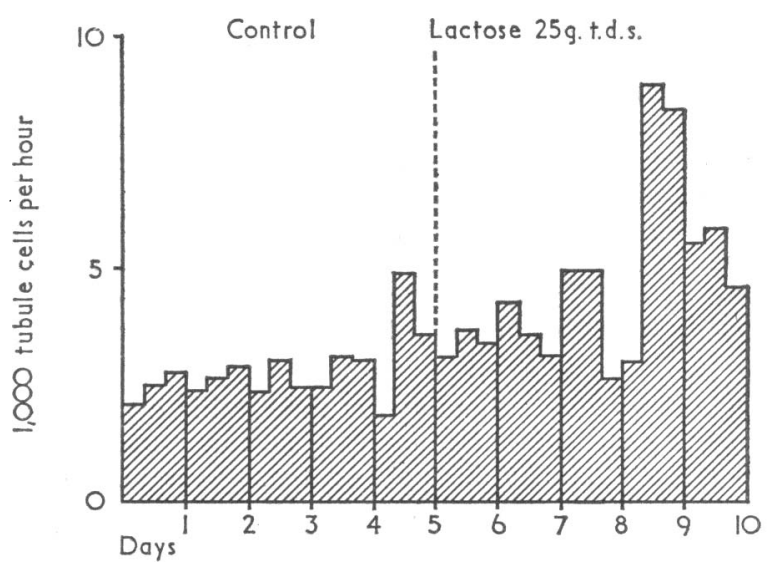

Fig. 4.-Increase in renal tubular cell excretion during administration of lactose 25 g. t.d.s.

Urine Flow Rates.-During the control periods the mean urine flow rate for the five subjects was $0.83 \mathrm{ml} . /$ minute. After the administration of frusemide there was a highly significant increase in the urine flow rates for all the subjects, the mean value being $1.57 \mathrm{ml}$./minute $(\mathrm{P}<0.0001)$. Urea also produced a significant increase in the flow rate; the mean value for the five subjects was $1.35 \mathrm{ml} . /$ minute $(P<0.05)$. Lactose did not have a significant effect on urine flow rates. Though the mean flow rate was $0.94 \mathrm{ml}$./minute, by comparison with the control rate this was not a significant increase $(P<0.1)$.

\section{Discussion}

Until recently techniques, such as the Addis count, which have been u'sed for counting cells excreted in the urine have been insufficiently accurate because they did not differentiate between white cells and renal tubular cells. The introduction by Prescott and Brodie (1964) of a staining method by which white blood cells, red blood cells, and renal tubular cells in urine may be distinguished has meant that urinary cell excretion rates can now be accurately measured, and by this method Prescott (1965) found that in healthy subjects aspirin, phenacetin, and caffeine produced definite increases in the output of renal tubular and red blood cells. The significance of the excretion of increased numbers of cells in the urine is not certain, but, as Prescott (1965) points out, it may indicate a toxic effect on the renal epichelium.

Our finding that frusemide will cause increases in the urinary cell loss of red cells, white cells, and tubular cells makes it unlikely that this hypothesis is correct. Frusemide has been widely used for several years in the treatment of chronic fluid retention, and so far there has been no report of it having a toxic effect on the kidneys. This, of course, is by no means the case with the analgesic drugs. The pathological changes produced by analgesics in the rat kidney (Kincaid-Smith et al., 1968) and in the human organ (Kincaid-Smith, 1967), together with the kidney changes demonstrated radiologically by Dawborn et al. (1966), indicate that analgesic drugs have a toxic effect on the kidney. The changes produced by frusemide in the present study do nothing to invalidate this view of the causation of an analgesic nephropathy, but the increased urinary cell loss induced by analgesic drugs cannot be taken as an indication that this pathological process is occurring. The similar but less pronounced changes in urinary cell loss provoked by both lactose and urea are additional evidence in support of this view.

The increase in urinary cell excretion produced by frusemide, lactose, and urea might simply be due to an increase in the urinary flow rates; certainly frusemide and urea caused a significant increase in urine production. This also would be an explanation for the change in urinary cell loss produced by caffeine which was found by Prescott (1965). Caffeine is 
a xanthine derivative, and has a diuretic action. However, lactose has been shown to have an effect on renal tubular cell excretion similar to that of frusemide and urea, but without a similar effect on the urinary flow rate. This effect of drugs on the kidney may explain the findings of Lindsay et al. (1967), who examined the effect of surgery on urinary white cell excretion. Although there was no difference in the urine production, they found a highly significant increase in the white cell excretion rate in $61 \%$ of the women studied. It is possible that this change was brought about by drugs used during and after surgery.

This work was carried out to test the specific hypothesis that drugs other than the analgesics and caffeine would influence urinary cell loss, and we have shown that this is so. However, this finding poses more problems than it resolves, and indicates many more lines of work. Thus, we have not studied the effect which frusemide, lactose, and urea may have on urinary solute load, for such an effect may account for the changes we have found; also by the use of different doses of frusemide variations in urine flow rate would indicate more precisely what effect such variations may have on urinary cell loss. Such effects, and the effect of other drugs on urinary cell loss, are obviously of considerable interest, and it is our intention to investigate the whole subject in greater detail.

We would like to thank Sir John Richardson, Bt., for proposing this study, and Dr. N. F. Jones for his criticism of the manuscript.

\section{REFERENCES}

Briggs, J. D., Kennedy, A. C., and Goldberg, A. (1963). Brit. med. 7., 2,

Chistoni, A., and Lapresa, F. (1909). Arch. Farmacol. sper., 8, 63.

Dawborn, J. K., Fairley, K. F., Kincaid-Smith, P., and King, W. E. (1966). Quart. F. Med., 35, 69.

Katz, Y. J., Velasquez, A., and Bourdo, S. R. (1962). Lancet, 1, 1144.

Kincaid-Smith, P., Saker, B. M., and McKenzie, I. F. C. (1968). Lancet, $1,24$.

Lindsay, R. M, Lunan, B., McGeachie, J., and Linton, A. L. (1967). Brit. med. F., 3, 83.

Little, P. J., and de Wardener, H. E. (1962). Lancet, 1, 1145.

Little, P. J., and de Wardener, H. E. (1962). Lancet, 1, 1145.

Prescott, L. F. (1965). Lancet, 2, 91.

Prescott, L. F., and Brodie, D. E. (1964).

Scott, R. W., and Hanzlik, P. J. (1916). F. Amer. med. Ass., 67, 1838

Vinci, G. (19905). Arch. Farmacol. sper., 4, 59.

\section{Preliminary Communications}

\section{Preservation of Isolated Heart for 72 Hours}

Brit. med. F, 1968, 4, 296-298

\begin{abstract}
Cummary : Isolated hearts of dogs have been preserved $S$ in a viable condition for 72 hours with hypothermic perfusion $\left(5^{\circ} \mathrm{C}\right.$.) at normal atmospheric pressure. On removal and connexion to the femoral artery and vein of another dog these hearts beat strongly and without failing until removed after six hours. In mechanical function and histological appearance they were virtually identical with control hearts. The most useful criterion of viability of the quiescent myocardium during storage was the change in coronary resistance with time of perfusion.
\end{abstract}

More than fifty heart transplants have effectively demonstrated the technical success of the actual insertion of the graft. This has served to highlight the two remaining major problems-the immune reaction, and the need to preserve the hearts as they become available. Humphries (1967) has stated the case for organ storage: "If the surgeon could preserve an organ well he could transplant it more deliberately, and perhaps even serotype it and so choose the best recipient. He can hope ultimately not only to preserve the damaged cadaver organ but to estimate its worth and even restore it towards normal." To this can be added that a decent interval between the removal of the graft and its insertion in the host should make it possible to achieve anonymity of the organ, and this, as recent events have shown, is particularly desirable when the organ is the heart (Brock, 1968).

Means of "estimating the worth" of an organ during storage are still rudimentary, but must be developed to a high degree of reliability in the case of the heart, for it must work immediately and in full after transplantation. Unlike the kidney, it can at best be supported for only a few hours, and if it then fails there can be no return to the circulatory equivalent of dialysis. Viability of the preserved heart is therefore mandatory.
Hearts have been stored in a viable condition for 24 hours by attaching them to the arterial and venous circulation of an "intermediate host" (Angell and Shumway, 1966); in vitro at normal temperature by perfusion with blood from an oxygenator for 11 hours (Levy et al., 1965); and, using a lung for gas exchange, for up to 24 hours (Yamade et al., 1965). Depression of the freezing-point of water with enormous pressures of 133 atmospheres absolute (ATA) (Robertson et al., 1964) has proved disappointing. Until now the most successful method has been a combination of hypothermic perfusion and hyperbaric oxygenation (Manax et al., 1966) ; hypothermic perfusion $\left(2^{\circ}\right.$ C.) alone did not produce viable hearts after 24 hours of storage, but the addition of 3 ATA, 8 ATA, and 15 ATA of oxygen achieved survival after 24,48 , and 72 hours respectively. Compression and decompression of the organ required 20-25 minutes for the 15 ATA mode.

The complexity of the combined perfusion, low temperature, and very high (15 ATA) pressures required for the longer period of storage, together with the difficulty of access during storage for functional studies, are likely to limit the exploitation of this technique. These factors, plus the conviction that perfusion rather than pressure offers the greater potential for storage, have led us to develop a method of hypothermic perfusion at normal atmospheric pressure.

\section{Method}

The experiments were carried out on dogs weighing 9-14 kg. Anaesthesia was induced with thiopentone sodium, and maintained with halothane. After heparinization the heart was arrested by external ventricular fibrillation; it was then removed, weighed, and flushed via the aorta to remove blood from the coronary vessels and to pre-cool the myocardium. Flushing was carried out with the filtered modified Krebs's solution (see below), first with $400 \mathrm{ml}$. at $20^{\circ} \mathrm{C}$., and then with $400 \mathrm{ml}$. at $5^{\circ} \mathrm{C}$. After flushing the heart was transferred to the perfusion circuit in the refrigerator. An ischaemic time of 15 minutes was adopted from the onset of ventricular fibrillation to the start of flushing. After 72 hours of perfusion the heart was removed from the refrigerator, the coronary vessels 